\title{
EXTREME CONDITIONING TRAINING: ACUTE EFFECTS ON MOOD STATE
}

EFEITOS AGUDOS DO TREINAMENTO DE CONDICIONAMENTO EXTREMO NOS ESTADOS DE HUMOR

EFECTOS AGUDOS DEL ENTRENAMIENTO DE CONDICIONAMIENTO EXTREMO EN LOSESTADOS

DEHUMOR

Emy Suelen Pereira ${ }^{1,2}$

(Physical Education Professional)

Walter Krause Neto'

(Physical Education Professional)

Atilio Sersun Calefi ${ }^{4}$

(Veterinarian)

Mariana Georgetti²

(Physiotherapist)

Larissa Guerreiro²

(Physical Education Professional)

Cesar Augustus Sousa Zocoler ${ }^{3}$

(Physical Education Professional)

Eliane Florencio Gama1,2

(Physiotherapist)

1. Universidade São Judas

Tadeu, Department of Physical

Education, Laboratório de Estudos

Morfoquantitativos e Imuno-

Histoquímica, São Paulo, SP, Brazil.

2. Universidade São Judas Tadeu,

Department of Physical Education,

Laboratório de Percepção e

Movimento do Corpo, São Paulo,

SP, Brazil.

3. Universidade São Judas Tadeu, Department of Physical Education, Laboratório de Movimento Humano, São Paulo, SP, Brazil. 4. Universidade de São Paulo, Faculdade de Medicina Veterinária e Zootecnia, Department of Pathology, São Paulo, SP, Brazil.

\section{Correspondence:}

Walter Krause Neto. Rua Taquari, 546, Mooca, São Paulo, SP, Brazil. 03166-000.

wild_krause@hotmail.com

Keywords: Behavior; Exercise; Motivation; Motor activity.

\section{RESUMO}

\begin{abstract}
Introduction: The search for strategies aimed at reducing daily stress is increasing in the current literature. As a result, several types of fitness training are constantly being investigated for their influence on mood states. However, we know little about strategies that use higher intensities. Objective: To investigate the acute effects of an extreme conditioning training (ECT) session on the mood states of individuals with or without prior experience in this type of training. Methods: Volunteers were divided into TRAINED $(n=10)$ and CONDITIONED $(n=$ 10) groups, undergoing a single 9-minute ECT session. Mood states (BRUMS scale) were analyzed at baseline, immediately afterwards, and after 30 minutes. Results: Anger, confusion and tension were significantly reduced in both groups immediately afterwards and post 30 minutes. The TRAINED group showed a significant reduction in fatigue 30 minutes after the end of the session. Effect size for all variables was considered small to moderate. The TRAINED group had significantly increased vigor immediately after the end of the session compared to baseline. However, the CONDITIONED group had significantly reduced vigor 30 minutes afterwards, in comparison to baseline. The increase in vigor in the TRAINED group was considered moderate (ES = 0.68), while the decrease in vigor in the CONDITIONED group was considered major ( $E S=-0.88$ ). Conclusion: An ECT session is powerful enough to induce significant, albeit small and moderate, changes in mood states in both trained and untrained individuals in this particular type of exercise. Level of evidence II, Therapeutic studies-investigation of treatment results.
\end{abstract}

Introdução: A busca por estratégias que visam reduzir o estresse cotidiano é crescente na literatura atual. Com isso, diversos tipos de treinamento físico são constantemente pesquisados por sua influência nos estados de humor. No entanto, pouco sabemos sobre as estratégias que usam intensidades mais elevadas. Objetivo: Investigar os efeitos da sessão de treinamento de condicionamento extremo (TCE) sobre os estados de humor de indivíduos com ou sem experiência prévia nesse tipo de treinamento. Métodos: Os voluntários foram divididos em grupos TREINADO $(n=10)$ e CONDICIONADO ( $n=10)$, submetidos a uma única sessão de TCE por 9 minutos. Os estados de humor (escala BRUMS) foram analisados no início do estudo, imediatamente após e depois de 30 minutos. Resultados: Raiva, confusão e tensão foram significativamente reduzidas em ambos os grupos imediatamente após e depois de 30 minutos. O grupo TREINADO mostrou redução significativa da fadiga 30 minutos após o término da sessão. 0 tamanho do efeito para todas as variáveis foi considerado pequeno a moderado. O grupo TREINADO teve aumento significativo do vigor imediatamente após o término da sessão, em comparação com o início do estudo. No entanto, o grupo CONDICIONADO teve redução significativa do vigor 30 minutos depois, em comparação com o valor basal. O aumento de vigor no grupo TREINADO foi considerado moderado (ES = 0,68), enquanto a redução do vigor no grupo CONDICIONADO foi considerada maior ( $E S=-0,88$ ). Conclusão: Uma sessão de TCE é poderosa o suficiente para induzir mudanças significativas, embora pequenas emoderadas, nos estados de humor de indivíduos treinados e não treinados neste tipo específico de exercício. Nível de evidência ll, Estudos terapêuticos - Investigação dos resultados do tratamento.

Descritores: Comportamento; Exercício; Motivação; Atividade motora.

\section{RESUMEN}

Introducción: La búsqueda de estrategias para reducir el estrés cotidiano es creciente en la literatura actual. Con ello, diversos tipos de entrenamiento físico son constantemente investigados por su influencia en los estados de humor. Sin embargo, poco sabemos sobre las estrategias que usan intensidades más altas. Objetivo: Investigar los efectos de la sesión de entrenamiento de condicionamiento extremo (EAE) sobre los estados de humor de individuos con o sin experiencia previa en ese tipo de entrenamiento. Métodos: Los voluntarios se dividieron en grupos ENTRENADO ( $n=$ 10) y CONDICIONADO ( $n=10)$, sometidos a una sola sesión del EAE durante 9 minutos. Los estados de humor (escala BRUMS) se analizaron al inicio del estudio, inmediatamente después y después de 30 minutos. Resultados: La ira, la confusión y la tensión se redujeron significativamente en ambos grupos inmediatamente después y después de 30 
minutos. El grupo ENTRENADO mostró una reducción significativa de la fatiga 30 minutos después del término de la sesión. El tamaño del efecto para todas las variables fue considerado pequeño a moderado. El grupo ENTRENADO tuvo un aumento significativo del vigor inmediatamente después del final de la sesión, en comparación con el inicio del estudio. Sin embargo, el grupo CONDICIONADO tuvo reducción significativa del vigor 30 minutos después, en comparación con el valor basal. El aumento de vigor en el grupo ENTRENADO se consideró moderado (ES $=0,68)$, mientras que la reducción del vigor en el grupo CONDICIONADO fue mayor ( $E S=-0,88)$. Conclusión: Una sesión de EAE es suficientemente poderosa para inducir cambios significativos, aunque pequeños y moderados, en los estados de humor en individuos entrenados y no entrenados en este tipo específico de ejercicio. Nivel de evidencia ll, Estudios

terapéuticos - Investigación de los resultados del tratamiento.

Descriptores: Conducta; Ejercicio; Motivación; Actividad motora.

\section{INTRODUCTION}

The improvement of general well-being has been emphasized by several sectors of society. The active lifestyle and regular practice of physical exercises are effective in protecting and preventing various neurological diseases. ${ }^{1}$ Thus, the practice of physical exercise, in general, has been recommended as a non-drug alternative to the treatment and/or prevention of chronic degenerative diseases ${ }^{2,3}$ and cognitive improvements. ${ }^{4}$

Most people experience the feeling of well-being (satisfaction and happiness with life) after physical exercise. ${ }^{5}$ In addition, the physical activity chosen may be associated with higher levels of well-being. Therefore, variations of mood states can be found with different forms of exercise modality. ${ }^{6}$

In concern to the modalities, the literature is consistent regarding the positive effects of running on the cognition and behavior. ${ }^{7,8}$ Additionally, strength and running exercises promote similar acute effects on mood states. ${ }^{9}$ However, not all physical training modalities present the same effects. ${ }^{10-12}$

Recently, moderate and high-intensity exercises are gaining prominence, as they bring similar benefits to others and require a shorter time investment. ${ }^{13}$ In the past few years, extreme conditioning training programs (ECT) became one of the most physical exercises searched by many people in Brazil. ${ }^{14}$ ECT is a high intensity/effort interval training methodology that has as main objective the improvement of all physical capacities (cardiorespiratory endurance, muscular endurance, strength, power, speed, coordination, flexibility, agility, balance, and precision). The great differential of this modality, compared to others, is presented by its challenging character and the large variability of stimulus presented in the training session. ${ }^{15}$ However, to date, there has been no research analyzing the impact of ECT training on the mood states of active individuals, whether or not trained in the modality. In this way, the present study aimed to evaluate the mood states of individuals trained and not trained in ECT, submitted to a training session of a high degree of physical effort.

\section{METHODS}

The present study was approved by the Ethics Committee of the São Judas Tadeu University, under the number CAAE (Certificate of presentation for ethical assessment) 37330614.7.0000.0089, pursuant to Resolution 466/12 of the National Health Council, by which regulates all methodological procedures in research with Human Beings.

All volunteers were informed of the objectives and procedures to be performed during this study, as well as their risks. The possible risks considered were:

1. Emotional discomfort when answering the questionnaires;

2. Bodily discomfort when performing the initial and final evaluations;
3. Fatigue and exhaustion during the high-intensity training session;

4. Psychological discomfort.

It should be noted that all these moments were accompanied by a professional who was able to assist and that the evaluations or sessions of the training program could be interrupted at any time a risk, discomfort or discomfort of the research participant was identified. If necessary, the volunteers were informed that the transport would be carried out to a prompt attendance of the hospital of the medical insurance of the individual or the public network.

\section{Participants}

Twenty adult men were divided into two groups based on the type of physical training practice in which they practiced: TRAINED $(n=10)$; Individuals practicing regular ECT and CONDITIONED ( $n=10)$; running athletes that never practiced ECT.

The following inclusion criteria were considered:

- Being male;

- Age range between 20 and 40 years old;

- Be active for the last 6 months uninterrupted, according to the classification by the International Physical Activities Questionnaire - IPAQ short version.

The following exclusion criteria were considered:

- Participating in two or more concurrent training programs;

- Regular use (last 4 weeks) of substances such as anabolic steroids, psychotropics, antibiotics, and corticosteroids.

\section{Experimental Protocol}

The groups were evaluated on three different days following the same standards. Firstly, individuals arriving at the indicated place were given all the information regarding the study and all the evaluations that would be developed. The informed consent form (TCLE) was read together with the participants and all doubts were clarified. After reading and agreeing to participate in the survey, they signed all the routes of the TCLE and received their copy.

After that, the volunteers answered the IPAQ, ${ }^{16}$ the Physical Activity Readiness Questionnaire (PAR-Q) and, finally, the General Anamnesis. Afterward, they performed the body composition evaluation and were, therefore, able to initiate the training protocol.

On the second day, all the volunteers did an exercise familiarization session in the exact sequence to be trained. This procedure was performed with the objective of reducing the coordinating bias. Thus, on the third day, all subjects performed the evaluation of BRUMS mood states, ${ }^{17}$ before and after the training protocol described below.

For data collection, both groups were initially assessed at baseline. They then trained a single ECT session, which consisted of a combination of high-intensity multi-joint exercises with a predetermined time of 9 
minutes. Being re-evaluated in the moments immediately after and 30 minutes after the end of the session.

The overall warm-up was composed of 3 sets of 10 movements of jump air squat and kettlebell swing. After this, the volunteers trained the high-intensity session composed of the following exercises:

WOD (Workout of the day) - AMRAP (As many reps as possible) in 9 minutes - 5 reps of Cleans, 10 Wall Ball reps and 20 Double-Unders or Single-Unders reps.

With each successful round, an extra movement was added to each exercise, except for the double-unders and / or single-unders exercise, making the training session more exhaustive. Example:

- First round: 5 cleans, 10 wall ball, 20 double-unders and / or single-unders;

- Second round: 6 cleans, 11 wall ball, 20 double-unders and / or single-unders;

- Third round: 7 cleans, 12 wall ball, 20 double-unders and / or single-unders and so on until completing the nine minutes of WOD.

It is worth mentioning that the TRAINED group performed the clean exercise with an external load equivalent to 80\% RM (stipulated in previous training) and the wall ball with $9 \mathrm{~kg}$. The load for the CONDITIONED group was purposely determined as singles load (20kg clean and $6 \mathrm{~kg}$ wall ball), for the safety of the volunteers and maintenance of the movement techniques. It is noteworthy that even the external loads were different between the groups, both trained with the same subjective perception of effort.

\section{Mood State Assessment (BRUMS)}

This test was performed before, immediately after and 30 minutes after the end of the training session. Brunel's mood states scale (BRUMS) was developed to allow rapid measurement of the mood state of populations composed of adults and adolescents.

Adapted from "Profile of Mood States - POMS", BRUMS contains 24 simple mood indicators. The volunteers responded in relation to these sensations, according to the scale of 5 points $(0=$ not at all, $1=$ a bit, 2 = moderate, 3 = enough; 4 = extremely). The form put in the question was: "HOW DO YOU FEEL NOW?".

The 24 items on the scale make up six subscales: anger, confusion, depression, fatigue, tension, and vigor. ${ }^{18}$ Each subscale contains four items. ${ }^{19}$ With the sum of the answers of each subscale, we obtained a score that can vary from 0 to 16 (volunteers took about 10 minutes to answer the questions).

\section{Statistical analysis}

Data are presented as the mean and standard deviation (SD). To test the normality of the data we used the Shapiro-Wilk test. In the analysis between training moments, ANOVA one-way was applied followed by the Tukey post hoc test. For the inferential analyzes between the groups, a student t-test was applied. The Cohen's d effect size calculation ${ }^{20}$ (ES = difference between pre- and post-intervention divided by pre-intervention SD) was used to evaluate the magnitude of training effects on the mood states. ES values ${ }^{20,21}$ were determined from very small (0.01), small (0.20), moderate (0.50), large (0.80), very large (1.20) and huge (2.0). For the calculation of the data we used SPSS software version 21.0 and the level of significance was $p \leq 0.05$.

\section{RESULTS}

\section{Anger}

Descriptive and effect size data are presented in Table 1 and 2. Training session of both groups significantly reduced anger in the moments immediately after $(p<0.01)$. However, only CONDITIONED group
Table 1. Descriptive data for anger, confusion, depression, fatigue, tension and vigor, measured for moments baseline, immediately after (IP) and 30 minutes post-session ( $+30 \mathrm{~min})$ between groups TRAINED $(n=10)$ and CONDITIONED $(n=10)$.

\begin{tabular}{|c|c|c|c|c|c|}
\hline Groups & Baseline & IP & $+30 \mathrm{~min}$ & $\mathrm{~F}$ & $P$ value \\
\hline \multicolumn{6}{|c|}{ Anger } \\
\hline TRAINED & $0.11 \pm 0.32$ & $0^{*}$ & $0.05 \pm 0.21$ & 2.928 & 0.057 \\
\hline CONDITIONED & $0.45 \pm 0.99$ & $0^{*}$ & $0.05 \pm 0.22^{*}$ & 7,153 & 0.001 \\
\hline P Value & $>0.05$ & $>0.05$ & $>0.05$ & - & - \\
\hline \multicolumn{6}{|c|}{ Confusion } \\
\hline TRAINED & $0.43 \pm 0.76$ & $0.16 \pm 0.37^{*}$ & $0.07 \pm 0.33^{*}$ & 5.730 & 0.004 \\
\hline C CONDITIONED & $0.35 \pm 0.58$ & $0.1 \pm 0.3^{*}$ & $0^{*}$ & 9.108 & 0.000 \\
\hline$P$ value & $>0.05$ & $>0.05$ & $>0.05$ & - & - \\
\hline \multicolumn{6}{|c|}{ Depression } \\
\hline TRAINED & $0.14 \pm 0.35$ & $0^{*}$ & $0.05 \pm 0.21$ & 3.859 & 0.024 \\
\hline C CONDITIONED & $0.25 \pm 0.44$ & $0.05 \pm 0.22$ & $0.1 \pm 0.44$ & 2.982 & 0.055 \\
\hline$P$ value & $>0.05$ & $>0.05$ & $>0.05$ & - & - \\
\hline \multicolumn{6}{|c|}{ Fatigue } \\
\hline TRAINED & $0.73 \pm 0.69$ & $0.75 \pm 0.75$ & $0.34 \pm 0.64^{*} \#$ & 4.773 & 0.01 \\
\hline C CONDITIONED & $1.1 \pm 0.9$ & $1.55 \pm 1.34$ & $1.45 \pm 0.99$ & 1.874 & 0.158 \\
\hline$P$ value & $>0.05$ & $<0.05$ & $<0.05$ & - & - \\
\hline \multicolumn{6}{|c|}{ Tension } \\
\hline TRAINED & $0.89 \pm 1.24$ & $0.34 \pm 0.68^{*}$ & $0.27 \pm 0.54^{*}$ & 6.483 & 0.002 \\
\hline C CONDITIONED & $0.7 \pm 0.72$ & $0.25 \pm 0.44^{*}$ & $0.4 \pm 0.59$ & 5.920 & 0.004 \\
\hline$P$ value & $>0.05$ & $>0.05$ & $>0.05$ & - & - \\
\hline \multicolumn{6}{|c|}{ Vigor } \\
\hline TRAINED & $2.36 \pm 0.97$ & $2.98 \pm 1.09^{*}$ & $2.48 \pm 1.36$ & 3.556 & 0.031 \\
\hline C CONDITIONED & $2.55 \pm 0.68$ & $2.35 \pm 0.8$ & $1.95 \pm 0.93^{*}$ & 5.680 & 0.004 \\
\hline$P$ value & $>0.05$ & $>0.05$ & $>0.05$ & - & - \\
\hline
\end{tabular}

Table 2. Effect size (ES) for anger, confusion, depression, fatigue, tension, and vigor, measured for moments immediately after and 30 minutes post-session between groups TRAINED $(n=10)$ and CONDITIONED $(n=10)$.

\begin{tabular}{c|c|c|c}
\hline Variable & Moments & Trained (ES) & Conditioned (ES) \\
\hline \multirow{2}{*}{ Anger } & Immediately after & -0.34 & -0.45 \\
\cline { 2 - 4 } & 30 minutes & -0.19 & -0.40 \\
\hline \multirow{2}{*}{ Confusion } & Immediately after & -0.35 & -0.43 \\
\cline { 2 - 4 } & 30 minutes & -0.47 & -0.60 \\
\hline \multirow{2}{*}{ Depression } & Immediately after & -0.40 & -0.45 \\
\cline { 2 - 4 } & 30 minutes & -0.25 & -0.34 \\
\hline \multirow{2}{*}{ Fatigue } & Immediately after & 0.03 & 0.50 \\
\cline { 2 - 4 } & 30 minutes & -0.56 & 0.39 \\
\hline \multirow{2}{*}{ Tension } & Immediately after & -0.44 & -0.62 \\
\cline { 2 - 4 } & 30 minutes & -0.50 & -0.42 \\
\hline \multirow{2}{*}{ Vigor } & Immediately after & 0.63 & -0.29 \\
\cline { 2 - 4 } & 30 minutes & 0.12 & -0.88 \\
\hline
\end{tabular}

maintained lower values at 30 min post-exercise $(p<0.05)$. Despite this, ES analysis showed that both groups induced only a small and moderate reduction of this feeling.

\section{Confusion}

Both groups induced a significant reduction of the confusion variable in both post-session moments $(p<0.01)$. ES revealed that the TRAINED group presented a mild-moderate effect, whereas the CONDITIONED group had a moderate effect on the reduction of this feeling.

\section{Depression}

Trained group induced a significant reduction of the depression variable, in both moments ( $p<0.01$ ). However, CONDITIONED group presented a tendency to lower depression ( $p=0.053)$. The ES calculation showed that both groups had a mild-moderate effect on this feeling. 


\section{Fatigue}

The TRAINED group demonstrated a significant reduction of fatigue 30 minutes after the end of the session ( $p<0.05$ ). However, no significant changes were found in the CONDITIONED group. The comparison between the groups revealed a significant difference for both post-session moments $(p<0.01)$. Both ES were considered to be moderate.

\section{Tension}

Both groups significantly reduced the tension at immediately post-session moment $(p<0.01)$. The TRAINED group maintained lower values at 30 min post-session ( $p<0.05)$. ES for both groups was shown to be moderate.

\section{Vigor}

The TRAINED group significantly increased vigor immediately after the end of the training session compared to the baseline $(p<0.05)$. However, the CONDITIONED group significantly reduced its vigor 30 minutes after the end, in comparison to the baseline $(p<0.05)$. The increase in vigor seen in the TRAINED group was considered moderate $(E S=0.68)$, while the reduction of the same in the CONDITIONED group was large ( $E S=-0.88)$.

\section{DISCUSSION}

In this study, we present as a strong point the practice of a real ECP protocol. The use of the AMRAP protocol is widely used in the training centers of this modality and the association of mood states with this type of training model brings us new tools to control the stress associated with the daily life of most people. In addition, the use of a real magnitude of the training loads enables the application and reproducibility of the data demonstrated here. However, the use of different training loads (intensity and volume) may be a limitation of the study, although this difference was intentionally used. Thus, we can highlight the following results of our study: 1) the ECT modality presented a small to moderate effect on mood states in both individuals trained or not trained in this modality, and such an effect persisted for 30 minutes after the end of the training session; 2) individuals trained in ECP have reduced sensation of fatigue and increased vigor after the training session, demonstrating positive effects of this modality on mood states.

Werneck et al ${ }^{9}$ evaluated the profile of mood states (POMS) in seven different training situations, consisting of resistance exercises and treadmill running, with different intensities and on alternate days. The authors demonstrated in their results that acute exercise sessions promoted changes in post-exertion mood, regardless of exercise type and intensity, thus confirming the findings presented here.
Some studies support the thesis that there is a time after the effort necessary to observe positive changes in the mood state, which can vary from 20 minutes to 3 hours after exercise. ${ }^{22-24}$ Mood variables in the study by Werneck et al, ${ }^{9}$ such as depression, anger, and mental confusion, were not statistically different, revealing that in this study they were less sensitive to acute exercise. Here, we demonstrate that a single short ( 9 minutes) exercise session with high volume and high effort can induce significant changes, although mild to moderate, in mood states.

The effect of exercise intensity on mood states does not seem to have conclusive effects in the literature, and some studies have shown favorable results, $22,25,26$ while others proved to be adverse. ${ }^{27,28}$ The reason for this divergence seems to be in the level of physical fitness and fitness of the individuals in relation to the trained modality. ${ }^{22,25,29}$ Hoffman and Hoffman ${ }^{29}$ investigated the acute response of individuals with different degrees of trainability, subject to the same level of perceived exertion during treadmill running. The findings demonstrated that a single session of moderate aerobic exercise improved vigor and decreased fatigue among regular exercisers despites caused no change in these scores for nonexercisers. Yet, it is true that despite the total disturbance of postexercise in exercisers and nonexercisers, regular exercisers have twice the effect of nonexercisers. Thus, the level of physical conditioning seems to exert a certain influence on the responses related to the mental profile of individuals submitted to an exercise session, although such influence is unknown ${ }^{30}$. Here, both groups tested showed some degree of trainability (on average two years of training in their respective modalities), even if not in the same modality. This fact makes it clear that previous levels of physical fitness may in some way positively influence mood states.

In general, studies indicate that individuals with a higher physical fitness have more significant responses on mood states and / or well-being after a physical exercise session, in addition to maintaining such benefits. ${ }^{25,29,30}$ However, we presented that this indication is not conclusive since due to the high degree of effort required in the training session, both groups demonstrated similar responses in the study outcomes. In addition, such response may also be associated with the previous training of the CONDITIONED group, whose type of training (running) to which they are adapted to do is indicated as an analgesic pathway stimulator. ${ }^{31-35}$

\section{CONCLUSION}

The results presented in this study allow us to conclude that a single ECT training session is powerful enough to induce significant, although small and moderate, changes in mood states of both trained and untrained individuals in the modality.

All authors declare no potential conflict of interest related to this article

AUTHORS' CONTRIBUTIONS: Each author made significant individual contributions to this manuscript. ESP (0000-0002-2385-3239)*: training, writing, and final reading of the manuscript; WKN (0000-0002-6881-0208)*: data analysis, statistics, writing and final revision. ASC (0000-0002-1859-2046)*: training and final revision. MG (0000-0001-7383-5808)*: training and final revision. LG (0000-0002-4217-8814)*: training and final revision. CASZ (0000-0002-8287-6481)*: training and final revision of the manuscript. EFG (0000-0002-9770-8819)*: supervision, writing, statistical analysis, intellectual concept and drafting of the entire research project. ${ }^{*} \mathrm{ORCID}$ (Open Researcher and Contributor ID).

\section{REFERENCES}

1. Spielman LJ, Little JP, Klegeris A. Physical activity and exercise attenuate neuroinflammation in neurological diseases. Brain Res Bull. 2016;125:19-29.

2. Pedersen BK, Saltin B. Exercise as medicine - evidence for prescribing exercise as therapy in 26 different chronic diseases. Scand J Med Sci Sports. 2015;25 Suppl 3:1-72.

3. Warburton DER, Nicol CW, Bredin SSD. Health benefits of physical activity: The evidence. CMAJ. 2006;174(6):801-9.

4. Song D, Yu DSF, Li PWC, Ley Y. The effectiveness of physical exercise on cognitive and psychological outcomes in individuals with mild cognitive impairment: A systematic review and meta-analysis. Int J Nurs Stud. 2018;79:155-164.
5. Stubbe JH, De Moor MHM, Boomsma DI, De Geus EJC. The association between exercise participation and well-being: A co-twin study. Prev Med. 2007;44(2):148-52.

6. Yeung RR. The acute effects of exercise on mood state. Journal of Psychosomatic Research 1996;40(2):123-41.

7. Karssemeijer EGA, Aaronson JA, Bossers WJ, Smits T, Olde Rikkert MGM, Kessels RPC. Positive effects of combined cognitive and physical exercise training on cognitive function in older adults with mild cognitive impairment or dementia: A meta-analysis. Ageing Res Rev. 2017;40:75-83.

8. Vivar C, van Praag H. Running Changes the Brain: the Long and the Short of It. Physiology (Bethesda). 2017;32(6):410-24. 
9. Werneck FZ, Bara Filho MG, Coelho EF, Ribeiro LS. Acute effects of exercise type and intensity on mood states. Rev Bras Ativ Fís Saúde. 2012;15(4)211- 7.

10. McGowan RW, Pierce EF, Eastman N, Tripathi HL, Dewey T, Olson K. Beta-endorphins and mood states during resistance exercise. Percept Mot Skills. 1993;76(2):376-8.

11. McGowan RW, Talton BJ, Thompson M. Changes in scores on the profile of mood states following a single bout of physical activity: heart rate and changes in affect. Percept Mot Skills. 1996;83(3):859-66.

12. NetzY, Lidor R. Mood alterations in mindful versus aerobic exercise modes.J Psychol. 2003;137(5):405-19.

13. Haskell WL, Lee IM, Pate RP, Powell KE, Blair SN, Franklin BA, et al. Physical activity and public health: updated recommendation for adults from the American College of Sports Medicine and the American Heart Association. Med Sci Sports Exerc. 2007;39(8):1423-34.

14. Sprey JWC, Ferreira T, de Lima MD, Duarte Jr A, Jorge PB, Santili C. An Epidemiological Profile of CrossFit Athletes in Brazil. Orthop J Sports Med. 2016;4(8):2325967116663706.

15. Heinrich KM, Patel PM, O'Neal JL, Heinrich BS. High-intensity compared to moderate intensity training for exercise initiation, enjoyment, adherence, and intentions: an intervention study. BMC Public Health, 2014;3;14:789.

16. Benedetti TRB, Mazo GZ, Barros MVG. Aplicação do Questionário Internacional de Atividades Físicas para avaliação do nível de atividades físicas de mulheres idosas: validade concorrente e reprodutibilidade teste-reteste. R Bras Ci e Mov. 2004;12(1):25-34.

17. Rohlfs ICPM, de Carvalho T, Rotta TM, Krebs RJ. Aplicação de instrumentos de avaliação de estados de humor na detecção da síndrome do excesso de treinamento. Rev Bras Med Esporte. 2004;10(2):111-116.

18. Rohlfs ICPM, Rotta TM, Luft CDB, Andrade A, Krebs RJ, de Carvalho T. Brunel Mood Scale (BRUMS): An Instrument for Early Detection of Overtraining Syndrome (A Escala de Humor de Brunel (Brums): Instrumento para detecção precoce da síndrome do excesso de treinamento). Rev Bras Med Esporte. 2008;14(3):176-81.

19. Brandt R, Herrero D, Massetti T, Crocetta T, Guarnieri R, Monteiro CBM, et al. The Brunel Mood Scale Rating in Mental Health for Physically Active and Apparently Healthy Populations. Health. 2016;8:125-32.

20. Cohen J. Statistical Power Analysis for the Behavioral Sciences. New York: Routledge; 1998

21. Sawilowsky S. New effect size rules of thumb. J Mod Appl Stat Methods. 2009;8(2):467-74.

22. Focht BC, Koltyn KF. Influence of resistance exercise of different intensities on state anxiety and blood pressure. Med Sci Sport Exerc. 1999;31(3):456-63

23. Hall EE, Ekkekakis P, Petruzzello SJ. The affective beneficence of vigorous exercise revisited. Brit J Health Psychol. 2002;7(Pt 1):47-66

24. Arent SM, Alderman BL, Short EJ, Landers DM. The impact of the testing environment on affective changes following acute resistance exercise. J Appl Sport Psychol. 2007;19(3):364-78

25. Tharion WJ, Rausch TM, Harman EA, Everett A, Willian J. Effects of different weight training routines on mood state. J Appl Sports Sci Res. 1991;5(2): 60-5.

26. Han MW, Yoon JR. The effects of running with various exercise intensities on hormone responses and mood states. Med Sci Sport Exerc. 1995;27:102.

27. Steptoe A, Kearsley N, Walters N. Acute mood responses to maximal and submaximal exercise in active and inactive men. Psychol Health. 1993;8(1):89-99.

28. Berger BG, Owen DR. Relation of low and moderate intensity exercise with acute moods changes in college joggers. Percept Mot Skills. 1998;87(2):611-21

29. Hoffman MD, Hoffman DR. Exercisers achieve greater acute exercise-induced mood enhancement than nonexercisers. Arch Phys Med Rehabil. 2008;89(2):358-63.

30. Petruzzello SJ, Hall E, Ekkekakis P. Regional brain activation as a biological marker of affective responsivity to acute exercise: Influence of fitness. Psychophysiology. 2001;38(1):99-106.

31. Oosterwijck JV, Marusic U, De Wandele I, Paul L, Meeus M, Moorkens G, et al. The Role of Autonomic Function in Exercise-induced Endogenous Analgesia: A Case-control Study in Myalgic Encephalomyelitis/Chronic Fatigue Syndrome and Healthy People. Pain Physician. 2017;20(3):E389-99.

32. Pitcher MH, Tarum F, Rauf IZ, Low LA, Bushnell C. Modest Amounts of Voluntary Exercise Reduce Pain- and Stress-Related Outcomes in a Rat Model of Persistent Hind Limb Inflammation. J Pain. 2017;18(6):687-701.

33. Kim YJ, Byun JH, Choi IS. Effect of Exercise on $\mu$-Opioid Receptor Expression in the Rostral Ventromedia Medulla in Neuropathic Pain Rat Model. Ann Rehabil Med. 2015;39(3):331-9.

34. Daenen L, Varkey E, Kellmann M, Nijs J. Exercise, not to exercise, or how to exercise in patients with chronic pain? Applying science to practice. Clin J Pain. 2015;31(2):108-14.

35. Sharma NK, Ryals JM, Gajewski BJ, Wright DE. Aerobic exercise alters analgesia and neurotrophin-3 synthesis in an animal model of chronic widespread pain. Phys Ther. 2010;90(5):714-25. 